\section{非ステロイド抗炎症剤による 胃粘膜障害の新しい評価}

内視鏡下薬物直接投与法による——

\section{星野照夫・遠藤 徹・草刈幸次・石田尚志 ${ }^{*}$}

\section{rapid communication}

Novel evaluation method of drug induced gastropathy using endoscopic sprayed drug delivery system

The effect of direct irritant action of anti-inflammatory powder drugs (all $25 \mathrm{mg}$ ) in canine gastric mucosa was studied using an endoscopic compressed air drug delivery system technique. Aspirin-induced mucosal lesions were limited to the target site of gastric mucosa in all dogs. Indomethacin (30\%) and diclofenac $\mathrm{Na}(40 \%)$ induced superficial gastritis at the pyloric antrum, but did not appear to spray sites. Predonisolone caused the erosion and edema throughout the stomach. No lesions were induced by lactose and sucralfate.

In the present study, we could observe the experimental gastric mucosal lesion at the target site of the gastric mucosa by an administration of a small amount of powdered drugs via an endoscope. The administration of powdered drugs by endoscopy is useful for the investigation of direct effects of those on the gastric mucosa.

Teruo Hoshino • Toru Endo • Koji Kusakari •

Masashi Ishida*

key words : endoscopy, ulcer, aspirin, indomethacin, diclofenac $\mathrm{Na}$

非ステロイド抗炎症剤 (non-steroidal antiinflammatory drug: NSAID)の内服により胃粘膜 病変が惹起されることが知られている。この事実 よりアスピリン，インドメサシンなどをラットに 経口投与して実験潰瘍病変を形成させることで, 抗潰瘍剤の薬物評価に利用されている1).しかし, これらの胃粘膜病変を生じさせる薬物は通常実験 動物に当該薬物を多量に経口投与することで作成 しており，そのため，病変の発生部位は一定して いない。また，発生した病変自体が直接的な粘膜 障害によるものと消化管吸収後に血行を介して起 こした障害などの複合的結果を示していると考兄 られる。

これまでわれわれは，内視鏡観察下に，各種薬

\footnotetext{
* First Department of Internal Medicine, St. Marianna University School of Medicine 聖マリアンナ 医科大学第一内科学教室
}

物の原末を胃粘膜局所に投与することが出来る投 薬装置を開発し, 実験潰瘍病変の発生部位を一定 化することに取り組んでいる2).

今回は，本装置を利用して数種の NSAIDsを 少量投与し, 薬物の消化管吸収後に生ずる粘膜障 害を極力排除し，これら薬剂の胃粘膜に対する直 接障害について内視鏡的に検討した.

\section{対象と方法}

(1) 薬物の投与法

市販のエアーダスターガン(IWATA Co., Tokyo）を改造し，薬物を装填する部分を取り付ける ことで投薬装置を作成した(図 1 ). カートリッジ に投薬する薬物を粉末化して入れ，装填部に装入 し，圧縮空気とともに薬物をカテーテルを経由し て内視鏡観察下に目的とする一定限局部位に散 布した。圧縮空気の圧力は压縮タンクの出口で $2 \mathrm{kgf} / \mathrm{cm}^{2}$ に設定した。な报，1回の薬物投与に 使用する空気量は, 大気圧で約 $60 \mathrm{ml}$ とした。今 回の実験に供した薬物はアスピリン，インドメサ シン, ジクロフェナックナトリウムであり, 比較 対照として，プレドニゾロン，乳糖およびスクラ ルファートを使用した。な括インドメサシン，ジ クロフェナックナトリウム，プレドニゾロンは特 級試薬(和光純薬製)を使用し，他はいずれも局方 品である. いずれの薬物も 1 回の投与量は $25 \mathrm{mg}$ とした。

\section{（2）内視鏡的評価法}

実験は体重 $10 \mathrm{~kg}$ の雑種犬 7 頭を用い, crossover 法で行った。 ペントバルビタールナトリウム 25 $\mathrm{mg} / \mathrm{kg}$ にて静脈麻酔後, 内視鏡(オリンパス社製 XQ-10)を胃に挿入し，薬物投与した。薬物散布 部位は胃体下部とし，1薬物についてイヌ 7 頭の 胃に 1 カ所に 1 回のみ投与して評価した.内視鏡 観察は，薬物投与直後， 3 時間後乞して 24 時間後 に施行し，胃粘膜の有無を判定した。ささらに， 1 週間後そして 2 週間後にも経過観察を行った。胃 粘膜障害が瘢痕あるいは治癒を示した例は薬物散 布部位を変更し,薬物をかえて検討を繰り返した。

\section{結 果}

薬剂散布直後の内視鏡観察では，いずれの薬物 においても，散布による胃粘膜からの出血は認め られなかった。すなわち，投薬投与圧 $2 \mathrm{kgf} / \mathrm{cm}^{2}$ 


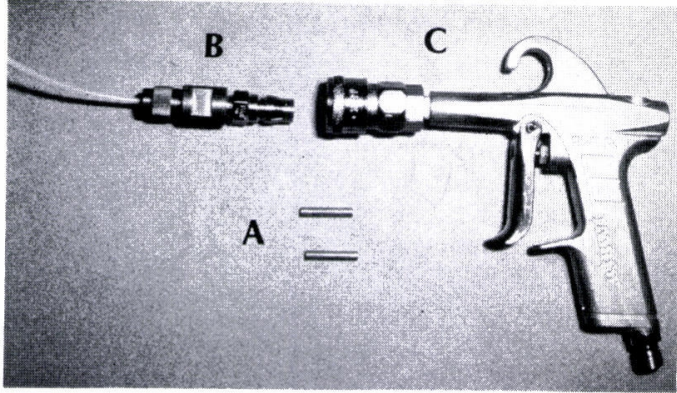

図 1 内視鏡用の薬物投与装置 カートリッジ（A）に投与したい薬物を入れ，これを 装填部（B）に装着，エアーガン（C）の圧縮空気を用 いて内視鏡観察下に目的とする部位に投与する。

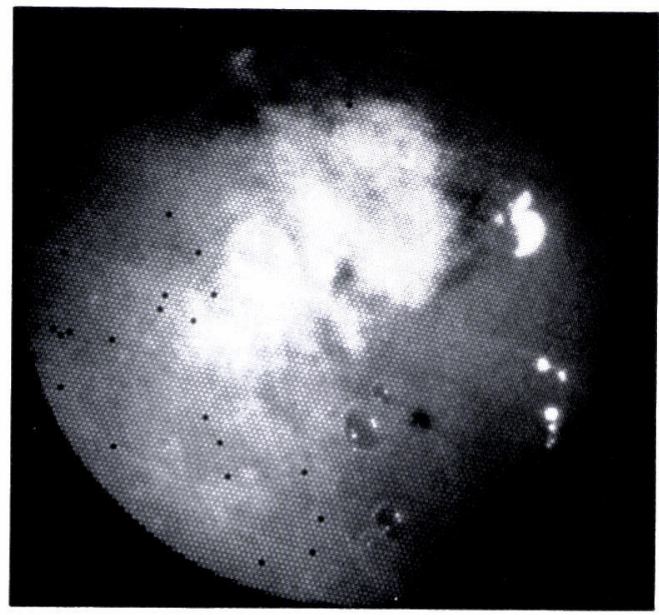

図 2 アスピリン投与 3 時間後

アスピリン粉末の残存が散布部位にみられ，投与部 扣よびその付近で点状出血が観察された。

による粉末薬物による機械的胃粘膜障害はみられ なかった。

いずれの薬物も散布直径は, $1.0 \mathrm{~cm}$ 程度であ った。

3 時間後の内視鏡観察では，アスピリン，イン ドメサシン，プレドニゾロン，スクラルファート で投与部位に薬物の残存を認めたが，ジクロフェ ナックナトリウム, 乳糖は溶解して扣り, 投与部 位には残存が観察されなかった。アスピリン散布 部位付近では点状出血を認めた(図 2 ).

24時間後の内視鏡観察では，アスピリン散布群 では投与部位に一致して胃粘膜障害(潰痻性病変) を 7 例全例 $(100 \%)$ 飞認めた(図 3 )。インドメサ シン散布群では投与部位には胃粘膜障害がみられ

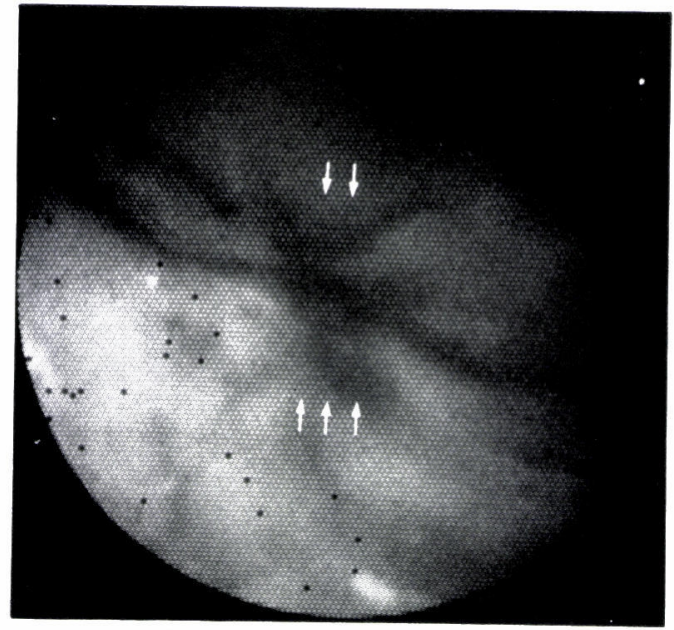

図３アスピリン投与 24 時間後

アスピリン投与部位に一致して, 潰瘍性病変がみら れた。

ず，投与部位とは異なる幽門部に浮腫を伴った櫛 状あるいは斑状発赤などの表層性胃炎に該当する 粘膜障害を 7 例中 2 例(30\%)に認めた。また，ジ クロフェナックナトリウムにおいても同様に，散 布部位には粘膜障害が発生せず，7 例中 3 例に幽 門部表層胃炎 $(40 \%)$ の変化を認めた。プレドニゾ ロン散布群では注注胃粘膜全体に発赤，浮腫と点 状性㠜血塊の散在性付着を全例(100\%) 飞認めた。 乳糖，スクラルファートでは全例，投与部位をは じめ，いずれの部位においても粘膜障害が観察さ れなかった，すなわち，本法を用いた薬物散布に よって胃粘膜障害は生じなかった。

1 週間後の観察では, アスピリン散布群の潰瘍 性病変は注济洀痕期にまで回復していた。

また，インドメサシン，ジクロフェナックナト リウム，プレドニゾロン散布による粘膜障害はす べて消失していた。

2 週間後の観察では, アスピリン散布群の潰瘍 性病変は瘢痕あるい治治癒した。

\section{考 察}

本装置は压縮ガスを用いて薬物を散布するた め，投与自体に上る粘膜障害が考兄られる22。本 実験では投与圧を $2 \mathrm{kgf} / \mathrm{cm}^{2}$ と小さくした結果， いずれの薬物の投与直後にも出血が認められなか ったこと，また，24時間後の乳糖，スクラルファ 一トにも粘膜障害が観察されなかった事実より， 実験方法气れ自体による胃粘膜への機械的刺激に 
表 1 非ステロイド抗炎症剤の投与で生ずる胃粘膜障害の種類

\begin{tabular}{l|c|c}
\hline & 投薬場所に病変形成 & 異所性の病変形成 \\
\hline タイプ 1 & + & + \\
タ イプ 2 & + & - \\
タイプ 3 & - & + \\
タイプ 4 & - & - \\
\hline
\end{tabular}

タイプ 1 ：直接障害を起こす薬物で，投与量が多く血行を介する作用も出現した。あるいは， 直接障害を起こさない薬物で，血行を介して作用したが，投与量が多く多発性に病 変を形成し，たまたま投与場所にも病変を形成した。

タイプ 2 ：直接障害を起こす薬物で，投与量が少なく血行を介する作用が出現しなかった。

タイプ 3 : 直接障害を起こさない薬物で, 血行を介して作用した薬物で病変を形成した。

タイプ 4 ：直接障害を起こさない薬物で, 投与量が少なく血行を介した作用の出現もなかった。

病変の形成は，投与部分の直接障害の有無と同時に，それぞれの薬物によって異なる $2.5 \mathrm{mg} /$ $\mathrm{kg}$ 当たりの薬効量が関与して出現する血行を介した作用の発現の有無により，4タイプに分 類，血行を介した作用が無視できるかどらかは，それぞれの薬物の作用強度によって異なる。

よる障害はなく, 障害は薬剤自身により引き起こ されたものと判断することが出来た.

従来のラットなど実験動物を用いた NSAIDs の経口投与により惹起された胃粘膜障害は，薬物 による直接的な粘膜障害と消化管より吸収後血行 を介してもたらされる障害との複合的な結果とし て，胃粘膜障害を評価していた。 また，これまで に薬物による直接的な胃粘膜障害を生理的状態で 肉眼的に評価できる方法は確立されていなかっ た。

本実験では，血行を介しての胃粘膜障害を極力 排除し，直接的な粘膜障害を䓯起する薬物を検索 するために，薬物投与量はいずれの場合もきわめ て少量の $2.5 \mathrm{mg} / \mathrm{kg}$ とした ${ }^{1)}$. しかし, 薬物によ っては，この投与量でも血行を介した粘膜障害が 出現することも考兄られ, 本実験で予想される 4 タイプの 胃粘膜障害を想定した(表 1)。すなわ ら，投薬場所に病変を形成する場合と投薬場所以 外の異所性の病変形成の組み合わせである。投薬 場所にだけ病変が形成すれば直接障害(タイプ 2) であり，異所性にだけ病変が形成すれば血行を介 した障害の可能性が高いことになる(タイプ 3 ).

この直接障害の判定は, 内視鏡観察下に本装置 を使用したことではじめて可能になると思われ る.すなわち胃粘膜の特定部位に限局して各薬物 を投与でき，さらに，投与薬物は少量でも局所に 対して高濃度となるため, 薬物そのものが示す直 接障害の判定が正確にできる利点を有している.
今回使用した NSAIDsをタイプ分類を考慮しな がら評価した。

アスピリンは強い胃粘膜直接障害を呈した(夕 イプ2).これはすでに, 1938年 Douthwate ら ${ }^{3)}$ がヒトの胃の内視鏡観察によって, 内服したアス ピリン顆粒の付着した胃粘膜部位に出血とびらん を観察し，アスピリンによる胃粘膜直接障害を指 摘した結果と一致している。乙かし，そ机以外の 薬剂についての胃粘膜直接障害の程度について検 討した場合には，体重当たりの NSAIDs の投薬 量が多いことが原因との推測がなされていたが, 確認手段がなかっだ、.

インドメサシンは $30 \%$ に，ジクロフェナックナ トリウムは $40 \%$ に，薬物投与部位とは異なる部 位に表層性胃炎を呈した(タイプ 3 およびタイプ 4 ).これは，体重当たりの薬物投与量和よび障 害発生部位が投与部位と異なる点から考光てみる と，直接的な胃粘膜障害ではなく，一度吸収され た楽剤が，血行を介して作用した障害と考えるほ らが合理的と思わ机る。NSAIDs 投与による胃粘 膜障害部位については，ラットを用いたこれまで の報告などから，プロスタグランジンを抑制(4)， 胃の蠕動運動元進 ${ }^{5)}$ など, 他の種々の要因も関与 しているものと思われる。

プレドニゾロンによる胃粘膜障害の特徵は，ほ ぼ胃全体にみられる障害所見であり, インドメサ シン, ジクロフェナックナトリウムと同様に, 胃 粘膜直接障害はなく, 吸収後に血行を介し障害を 
もたらすものと考えられた(タイプ1).

胃粘膜に直接散布された NSAIDs が粘膜防御 機構に影響を与える一つの因子として，胃粘膜 での薬物の溶解度が関与することが予想される。 さらに高濃度，高浸透圧の薬物の影響により粘膜 防御機構の破綻することも想像された。しかし， 今回の結果は，溶解度の低いアスピリンには粘膜 直接障害が認められたが，同様に難溶解性である インドメサシン，プレドニゾロンによる粘膜障害 は直接障害とは考えがたく，薬物の溶解性の大小 は粘膜直接障害と関係しないものと考えている. 直接薬物を胃内に投与する本装置は，今回使用 の薬物以外の NSAIDsをはじめ抗生物質など, 種々の薬物を溶解することなく，胃内の特定局所 に投与することを可能とし，胃粘膜障害について の正確な検討が容易に行兄る利点がある。また，

NSAIDsによる胃粘膜障害の発生を抑制させる $\mathrm{H}_{2}$ ブロッカーをはじめ6,7), 種々の抗潰瘍薬の薬 理作用の検討にも応用でさる。ささらに，本装置を 活用し，内視鏡下に各種治療薬剂を粘膜病変に投 与する直接加療法も可能と考兄ている.

稿を終えるにあたり，ご指導いただきました抂 マリアンナ医科大学, 難病センター柳川 明助 教授に深謝いたします。
なお，本論文の一部については，第 1 回欧州連 合消化器病週間で報告した。

\section{文 献}

1）中澤三郎, 森賀本幸: 実験潰瘍。医学図書出版, 1982, p 12.

2) Hoshino, T., Ozeki A., Endo, T. et al.: Transendoscopic projectile drug delivery. Gastroenterologia Japonica 25: 659, 1990.

3) Douthwaite, A.H., Lintott, G.A.M.: Gastroscopic observation of the effect of aspirin and certain other substance on the stomach. Lancet 2: 1222-1225, 1938.

4) Vane, J.R.: Inhibition of prostaglandin synthesis as a mechanism of action for aspirin-like drugs. Nature (New Biol.) 231: 232, 1971.

5) Takeuchi, K.: Importance of gastric motility in the pathogenesis of indomethacin induced gastric lesion in rats. Dig. Dis. Sci. 31: 1114, 1986.

6) Yanagawa, A., Mizushima, Y., Endo, T. et al.: Prophylactic efficacy of the $\mathrm{H}_{2}$-blocker ranitidin against gastroduodenal lesions caused by non-steroidal anti-inflammatory drugs (NSA IDs): controlled trial study. Japanese J. Rheumatology 3: 275-287, 1991.

7) Graham, D.Y., Agrawal, N.M., Roth, S.H.: Prevention of NSAID induced gastric ulcer with misoprostol: multicentre, double blind, placebo controlled trial. Lancet 2: 1277-1280, 1988. 